\title{
Understanding the process of adaptation to climate change by small-holder farmers: the case of east Hararghe Zone, Ethiopia
}

\author{
Yibekal A Tessema ${ }^{1 *}$, Chanyalew S Aweke ${ }^{2}$ and Getachew S Endris ${ }^{2}$
}

\author{
* Correspondence: \\ yibekalab@gmail.com \\ ${ }^{1}$ School of Agricultural Economics \\ and Agribusiness, Haramaya \\ University, Dire Dawa, Ethiopia \\ Full list of author information is \\ available at the end of the article
}

\begin{abstract}
This study examined smallholder farmers' level of perception about climate change, source of information on climate change, types of adaptation strategies, factors influencing adaptation choices and barriers to adaptation in Eastern Hararghe Zone, Ethiopia. The surveyed farm households in the study area perceived at least one aspect of climate change primarily through their life experience. Planting trees is the major adaptation measure and 89.1 percent of the farmers took this adaptation strategy. Most farmers (96 percent) believe that deforestation is the main cause of climate change and the choice of farmers to plant trees as an adaptation strategy may be partly a mitigation strategy. However, the majority (49.6 percent) of the households employed at least one adaptation response on top of tree planting. The other adaptation strategies include: early planting, terracing, irrigation and water harvesting. The main source of information for these adaptation strategies for 58.4 percent of the respondents is from extension advice. Results of a multinomial logit model showed that non-farm income, farmer- to-farmer extension, access to credit, distance to selling markets, distance to purchasing markets, and income affect the choice of adaptation strategies. Finally, the study identified lack of information as the most important barrier to climate change adaptation. The other barriers include: lack of farm inputs, shortage of land, lack of money, lack of water and shortage of labor.

Keywords: Climate change; Ethiopia; Perception; Adaptation; Multinomial logit model
\end{abstract}

\section{Background}

Climate change has adversely affected the livelihoods of people in developing countries where a large proportion of the population is heavily dependent on agriculture. Similarly, climate change has exacerbated poverty, food insecurity and vulnerability of agrarian communities in Sub-Saharan Africa (Akponikpè et al. 2010; Bryan et al. 2009). Ethiopia, a country located in the Horn of Africa, where the agricultural sector accounts for about 52 percent of the GDP and 85 percent of the foreign exchange earnings, and employs about 80 percent of the population (CSA Central Statistics Authority 2004) could be a typical example of the impact of climate change on the vulnerable rural communities in the developing world.

A recent mapping on vulnerability and poverty in Africa has positioned Ethiopia as one of the most vulnerable countries in the continent with the least adaptive capacity to climate change. In fact, the country has suffered from at least five major national 
droughts since 1980, not mentioning numerous local droughts all over the country. In the years between 1999 and 2004 alone, more than half of all households in the country faced at least one major drought. These cycles of drought have effectively kept the population in vicious poverty nullifying the endeavors of the population in creating assets and increasing its food security status (ILRI 2006; Stige et al. 2006; ACCCA 2010).

However, the impact of climate change is not limited to the occurrence of droughts (Lautze et al. 2003). Other important climatic variables are also changing implying the multiple repercussions of the change in climate. Over the past decade, average minimum and maximum temperatures of the country have increased by around $0.25^{\circ} \mathrm{C}$ and $0.1^{\circ} \mathrm{C}$ respectively. Further, it is expected that in the year 2050, mean temperature will increase by $1.7-2.1^{\circ} \mathrm{C}$ (Tadege 2007). Most climate models support this increase in temperature. However, there is a contradiction as to the change in precipitation, where both increase and decrease in precipitation are forecasted depending on the climate models employed (Strzepek and Mccluskey 2006). Nevertheless, high variability in precipitation is observed in the country over the past decade (Deressa et al. 2011).

The change in climate is inevitable, at least in the near future, and Ethiopian farmers are now faced with adapting to this inevitable change in climate. Following IPCC (2001), adaptation to climate change refers to the "adjustment in natural or human systems in response to actual or expected climatic stimuli or their effects, which moderates harm or exploits beneficial opportunities". Adaptation could be effected at different scales: individual or farm-level, and national or international level. Even though there will be some autonomous adaptation at farm-level, this adaptation is inadequate and needs the intervention of institutions like governmenet (Maddison 2007; Smit and Pilifosova 2001). Adaptation actions at national or international level, however, entail an understanding of the process of autonomous adaptations at farm-level (Bryan et al. 2009).

Adaptation at farm-level involves two stages: perceiving the change in climate, and deciding whether to adapt or not, or which adaptation strategy to choose (Maddison 2007). There are still important questions on perception that need to be addressed, such as: Are farmers able to perceive the change in climate in the long run? Which changes are they able to perceive? What economic, social and institutional factors influence their level and speed of perception (Vedwan and Rhoades 2001; Falco et al. 2011; Deressa et al. 2009)? Perception is not, however, an adequate condition for adaptation. Farmers who have perceived the change in climate may not adapt or the nature of their adaptaion respones may vary as a result of a complex interplay between social, econmic and institutional factors (Maddison 2007; Maharjan et al. 2011; Bryan et al. 2009).

There is a large deficit of information on the process of adaptation in the developing world including Ethiopia (Smit and Pilifosova 2001; McSweeney et al. 2010). There are currently few research outputs in Ethiopia, almost all focused only to the Nile Basin of the country. Deressa et al. (2009), Deressa et al. (2011) and Falco et al. (2011) studied the perception and adaptation process in the Nile Basin of Ethiopia. They were able to identify factors that affect perception, adaptation decisions, and also highlighted the main barriers to adaptation in the study areas. On the other hand, Maddison (2007) and Bryan et al. (2009) compared the adaptation process in Ethiopia with other African countries, again based on the survey in the Nile basin of Ethiopia. All the studies carried out in the Nile Basin of Ethiopia were dependent on a single survey made 
during 2004/2005 on 1,000 farmers. However, ACCCA (2010) studied the nature of adaptation in the drought prone areas of Tigray, northern Ethiopia, based on a survey of 160 farmers.

The studies carried out so far are only limited to the Nile Basin of Ethiopia. There is a need to study the other parts of the country: the southern and eastern parts. There are regions in the country which could provide new insights on the adaptation process at farm-level. East Hararghe Zone of Oromia regional state could be a very good example in this respect. The Zone is characterized by farmers with very small average landholdings, even compared to the national and regional average, and follows a mixed crop-livestock production system consisting of cash crops (such as Khat and coffee) and cereals, unlike most of the areas in the Nile Bain. The Zone is also one of the food insecure areas of the country having a large population with frequent need for emergency food aid (Niemistö 2011). Hence, a study on adaptation to climate change in this area could supplement the current knowledge on the adaptation process in the country and could subtantially contribute to plan development interventions in the Zone. Moreover, it seems that most studies (Deressa et al. 2011; Deressa et al. 2009; Falco et al. 2011; Bryan et al. 2009) assumed that farmers have perceived climate change gradually by themselves and did not explicitly ask the source of their perception on climate change, which could be training given by extension agents. Unlike many studies, this study also seprately considers distance to selling markets and distane to purchasing markets as determinants of adaptation decisions.

This study, therefore, investigated the whole adaptation process starting from perception to adaptation responses in Eastern Hararghe Zone. It examined the process and degree of smallholder farmers' perception and adaptation to climate change in the study area. It also identified factors governing smallholder farmers adaptation responses and the most important barriers to adaptation.

\section{Methods}

\section{Study area, sampling and data collection}

The study area is East Hararghe Zone, Oromia National Regional State, Ethiopia. It is located in the eastern part of the regional state and the country. Following the national census in 2007, the Zone with an area of $17,930 \mathrm{~km}^{2}$ has a total population of 2,723, 850 and 580,735 households (CSA 2007).

The study employed a multistage sampling technique. In the first stage, out of the 18 Woredas (districts) in the Zone, three Woredas were purposively selected to include different attributes of Eastern Hararghe Zone with respect to agro-ecological zones (traditional typology of agro-ecological zones in the country), and agricultural production systems. The selected Woredas are Haramaya, Kersa and Babile. Haramaya Woreda has an area of $561.6 \mathrm{~km}^{2}$ and a rural population of 154,690 and is found in the northern central part of the Zone. Kersa is located in the northern part of East Hararghe Zone and has an area of $544.9 \mathrm{~km}^{2}$ that is home to about 119,542 rural inhabitants. Both Haramaya and Kersa are characterized predominantly by Woinadega (middle land 1500-2500 m.a.s.l.) agroecology and mixed crop-livestock farming is the dominant production system. On the other hand, Babile Woreda is found in the eastern part of the study area with an area of $3,022 \mathrm{~km}^{2}$ and with a rural population of 42,858. The largest part of this Woreda falls under Kolla (lowland, 500-1500 m.a.s.l) agro-ecological zone. In addition to the mixed 
crop-livestock farming, the agro-pastoral production system is an important characteristic of the Woreda (ONRSPO n.d.).

From the selected Woredas, 2 Kebeles (the smallest administrative unit) were randomly selected and from each Kebele 20 households for Haramaya and Kersa, and 15 households from Babile were randomly selected and included in the study. A smaller sample size was allocated to Babile as it represents a relatively smaller proportion of the population in East Hararghe Zone (ONRSPO n.d.). Hence, a total of 110 farm households were included in the study and the survey was carried out in 2012. However, during data processing, we dropped one of the questionnaires as it had missing values. The non-missing variables of the questionnaire were examined and no peculiar characteristics were found justifying the decision for list wise deletion, which is the best option under such situations (Allison 2002).

To collect the data, a semi-structured interview schedule was employed. Enumerators were trained for one day to familiarize them with the issues of climate change, farmlevel adaptation to climate change, the significance of research on climate change adaptation, and the basic concepts in sampling, interviewing and processing data.

\section{Data analysis}

This study employed both qualitative and quantitative analysis techniques. The qualitative analyses used interpretations, comparisons and arguments. The quantitative analyses made use of both descriptive and inferential statistical techniques. The descriptive statistical techniques applied in the study include percentages and graphs. Inferences are made using a multinomial logit model (MNL). MNL is widely employed in climate change adaptation (e.g., Deressa et al. 2009; Sofoluwe et al. 2011; Gbetibouo 2009) and technology adoption (e.g., Uaiene et al. 2009; Paudel et al. 2011; Jariko et al. 2011) studies. It is employed when the dependent variable has more than two outcomes or, in our case, more than one adaptation response to climate change (Madalla 1983; Greene 2003).

To describe the MNL model, let y denote a random variable taking on the values $\{0 ; 1 ; \ldots . . ; j\}$ where $\mathrm{J}$ is a positive integer and $\mathrm{x}$ denote a set of conditioning variables. In our study, y would be adaptation measures taken by households whereas $\mathrm{x}$ represents the explanatory variables hypothesized to influence the choice of the available adaptation options. The MNL model is employed to show how ceteris paribus changes in the elements of $x$ influence the response probabilities, $P(y=j \mid x), j=0,1, \ldots, J . P(y=j \mid x)$ is known after determining the probabilities for $j=0,1,2, \ldots, \mathrm{J}$, which must sum to unity.

The MNL model has response probabilities given as Equation (1):

$$
P(y=j 1 x)=\frac{\exp (x \beta j)}{1+\sum_{i \neq j} \exp (x \beta j)}, j=1, \ldots, J
$$

The parameter estimates of the MNL model only show the direction of the relationship between the dependent and independent variables. Therefore, to determine the actual magnitude of change or probabilities, the marginal effect of the explanatory variables, Equation 1 is differentiated over the explanatory variables to give Equation (2):

$$
\frac{\partial P(y=j l x)}{\partial x_{k}}=P(y=j l x)\left[\beta_{i k}-\frac{\sum_{i \geq 1} \beta_{i k} \exp (X \beta i)}{1+\sum_{i \geq 1} \exp (X \beta i)}\right]
$$


The MNL, however, works under the assumption of the Independent Irrelevant Alternatives (IIA). Following this assumption, the odds of any two outcomes are independent of the remaining outcomes available. Hence, omitting or adding outcomes should not affect the odds of the remaining outcomes (Long and Freese 2001). The fitted MNL model was first checked to make sure that it does not violate this assumption.

\section{Empirical specification of model variables}

The dependent variable is farmers' choice of no adaptation, tree planting as a sole response, and tree planting and at least one additional measure. Farmers usually adopt more than one adaptation strategy at a time and the dependent variable is defined in a way that provides mutually exclusive outcomes. Farmers' choice of adaptation strategies is made in the context of households' socio-economic characteristics, institutions, and agro-ecological settings. Hypothesized factors are discussed below and the description of each explanatory variable is given in Table 1.

The agro-ecological settings of farmers such as climate and soil are expected to influence their adaptation to climate change. Evidence shows that farmers in drier and hotter climate are more likely to respond to climate change than farmers in cooler and wetter areas (Deressa et al. 2009). In Ethiopia, according to the country's traditional agro-ecological zones, areas categorized as Kolla (lowland, 500-1500 m.a.s.l) are characterized by relatively hotter and drier climate whereas Woinadega (middle land 1500-2500 m.a.s.l.) and Dega (highland, 2500-3500 m a.s.l.) are wetter and cooler (Deressa et al. 2009). In our study the sampled Kebeles fall under either Kolla or Woinadega. Hence, it is hypothesized that farmers living in Kolla are more likely to adapt to climate change than in Woinadega. Access to water for irrigation is hypothesized to negatively affect farmers' adaptation to climate change. This is based on the argument that farmers who have access to irrigation water are more resilient to climate change and are less likely to take adaptation measures (Gbetibouo 2009).

Female-headed households in Ethiopia in general and in East Hararghe in particular are expected to be less likely to adapt due to their limited access to land, information, inputs and institutions as a result of traditional social barriers (Wilson and Getnet 2011). However, Nhemachena and Hassan (2007) found that female-headed households are more likely to take up adaptation measures than male-headed households. The authors explain that females are engaged in more farm activities than males and have better farm experience and information. Although this finding has sound grounds, our study proposes that the argument in the contrary is more probable to prevail in the study area (Wilson and Getnet 2011) and hypothesized that male-headed households are more likely to adapt to climate change.

Farmers with more years of farming experience are more capable of assessing the available technologies and making adaptation decisions (Gbetibouo 2009). On the contrary, more experienced or older farmers tend to be risk-averse and lag behind in adoption decisions. There is no final consensus on how age affects adoption decisions (Adesina and Baidu-Forson 1995). The more a farmer is educated, the more likely he/she is to access information, perceive and adapt to climate change (Adesina and Baidu-Forson 1995; Maddison 2007). Hence, a positive relationship between level of education and adaptation decisions is expected. 
Table 1 Description of the independent variables

\begin{tabular}{|c|c|c|c|}
\hline Explanatory variables & Mean & S.D. & Description \\
\hline Local agro-ecology (Mid-land) & 0.69 & 0.47 & $\begin{array}{l}\text { Dummy takes the value of } 1 \text { if Woinadega and } \\
\text { zero otherwise (Low land) }\end{array}$ \\
\hline Non-farm income & 0.71 & 0.46 & Continuous \\
\hline $\begin{array}{l}\text { Educational level of the household head- } \\
\text { able to read and write }\end{array}$ & 0.20 & 0.40 & $\begin{array}{l}\text { Dummy takes the value of } 1 \text { if read and write and } \\
\text { zero otherwise }\end{array}$ \\
\hline $\begin{array}{l}\text { Education level of the household head- } \\
\text { primary school or higher }\end{array}$ & 0.16 & 0.36 & $\begin{array}{l}\text { Dummy takes the value of } 1 \text { if primary and above } \\
\text { and zero otherwise }\end{array}$ \\
\hline Gender of the household head & 0.92 & 0.28 & $\begin{array}{l}\text { Dummy takes the value of } 1 \text { if male and zero } \\
\text { otherwise }\end{array}$ \\
\hline Access to irrigation water & 0.13 & 0.34 & $\begin{array}{l}\text { Dummy takes the value of } 1 \text { if there is access and } \\
\text { zero otherwise }\end{array}$ \\
\hline $\begin{array}{l}\text { Farming experience of the household head } \\
\text { in years }\end{array}$ & 31.35 & 17.32 & Continuous \\
\hline Farm size in hectares & 1.24 & 0.81 & Continuous \\
\hline Access to food aid of the household & 0.39 & 0.49 & $\begin{array}{l}\text { Dummy takes the value of } 1 \text { if there is access and } \\
\text { zero otherwise }\end{array}$ \\
\hline Land ownership of the household & 0.91 & 0.29 & $\begin{array}{l}\text { Dummy takes the value of } 1 \text { if owned and zero } \\
\text { otherwise }\end{array}$ \\
\hline Farmer-to-farmer extension & 0.67 & 0.47 & $\begin{array}{l}\text { Dummy takes the value of } 1 \text { if there is access and } \\
\text { zero otherwise }\end{array}$ \\
\hline Access to credit services & 0.30 & 0.46 & $\begin{array}{l}\text { Dummy takes the value } 1 \text { if there is access and } \\
\text { zero otherwise }\end{array}$ \\
\hline Access to extension services & 0.83 & 0.38 & $\begin{array}{l}\text { Dummy takes the value } 1 \text { if there is access and } \\
\text { zero otherwise }\end{array}$ \\
\hline $\begin{array}{l}\text { Distance from selling market in walking } \\
\text { hours }\end{array}$ & 2.93 & 4.75 & Continuous \\
\hline $\begin{array}{l}\text { Distance from purchasing market in walking } \\
\text { hours }\end{array}$ & 1.67 & 1.68 & Continuous \\
\hline Family size of the household & 7.28 & 3.05 & Continuous \\
\hline Annual income of the household & 11548 & 12216 & Continuous \\
\hline $\begin{array}{l}\text { Livestock ownership in tropical livestock } \\
\text { units (TLU) }\end{array}$ & 3.24 & 1.88 & Continuous \\
\hline
\end{tabular}

Household wealth (land, livestock and income) highly influences adoption decisions of farmers (Deressa et al. 2009; Asfaw et al. 2011). Shortage of land is observed to be one of the major barriers in adaptation to climate change (Bryan et al. 2009; Maddison 2007) and land size (farm size) was hypothesized here to have a positive relation with adaptation to climate change. A related institutional issue with land is land tenure. Previous studies observed that farmers who own their farm land are likely to take adoption measures, particularly if the investment required for adaptation is tied to the land (Gbetibouo 2009; Nhemachena and Hassan 2007). It is, therefore, hypothesized that ownership of land encourages adaptation to climate change.

Apart from farm size, wealth of farmers in terms of higher income and livestock ownership facilitates adoption of technologies. Wealthier farmers are more likely to use their financial resources to acquire new technologies and are less risk-averse to experiment them. It is also argued that the more wealth a farmer has, the more likely he/she is to access information, credit and extension services (CIMMYT 1998). Hence, higher farm and non-farm income, and livestock ownership are expected to influence adaptation positively. According to Foster and Rosenzweig (2010), wealthier farmers 
are advantageous in adoption particularly due to lack of well-developed credit and insurance institutions. Thus, better access to credit hastens adoption (CIMMYT 1998) and it is hypothesized here to facilitate adaptation to climate change.

Household size can influence adaptation because of its association with labor endowment. It is argued that a larger household size enables the adoption of technologies by availing the necessary labour force in one hand (Croppenstedt et al. 2003) and enabling the generation of additional income from extra labor invested in off-farm activities (Yirga 2007). It is, therefore, expected to positively influence adaptation to climate change. Extension services foster adaptation through enhancing farmers' awareness of climate change and knowledge on adaptation measures (Falco et al. 2011; Doss 2003; Nhemachena and Hassan 2007). In this study, both formal (public) and informal (farmer-to-farmer) extension services are hypothesized to facilitate adaptation to climate change. Farmer-to-farmer extension is also used here to serve as a proxy for social capital. Enhanced social capital ensures better access to information, credit, and facilitates cooperation for actions that have positive externalities which are not internalized at the level of individual decision makers (Hogset 2005 cited in Katungi 2007). Isham (2000) and Abodi et al. (2007) showed the importance of this variable in encouraging adoption of technologies by farmers. Thus, the positive relation of farmer-to-farmer extension with adaptation is further supported in relation to social capital.

Markets serve as a means of sharing and exchanging information (Maddison 2007) and also enhance the returns from technology (Jack 2011). As a result, farmers close to input and output markets are in a better position to take adaptation measures, and distance to input and output markets is expected to be inversely related with adaptation. A final factor that is included in this study is food aid. Food aid has an insurance effect (Barrett 2006) and may encourage farmers to adopt new technologies. For example, Bryan et al. (2009) have shown that food aid increases the probability of adaptation among the poorest farmers. This study, therefore, expects that food aid enhances adaptive capacity to climate change.

\section{Results and discussion}

\section{Perception of climate change}

There are differences among farmers in how they perceive changes in temperature and precipitation (Figures 1 and 2). 91.2 percent of the respondents perceived an increase in temperature over the last 20 years while 5.3 and 3.5 perceived no change and decrease in temperature respectively. On the other hand, 90.3 percent of respondents perceived decrease in precipitation while 6.2 and 2.6 percent perceived no change and increase in precipitation respectively. Besides, 0.9 percent indicated precipitation is variable rather than agreeing either on an increase or decrease of rainfall. However, all the farmers have perceived at least one aspect of the change in climate indicating a high level of perception among farmers in the study area. A Heckman selection test was run to see whether farmers perceiving no temperature or precipitation change introduce selection bias in our analyses. The inverse Mills ratio term is statistically not different from zero at 10 percent level of significance $(\mathrm{p}=0.2985$ and $\mathrm{p}=0.2318$ for perceiving no precipitation and no temperature change respectively), indicating no statistically significant indication of selection bias. 


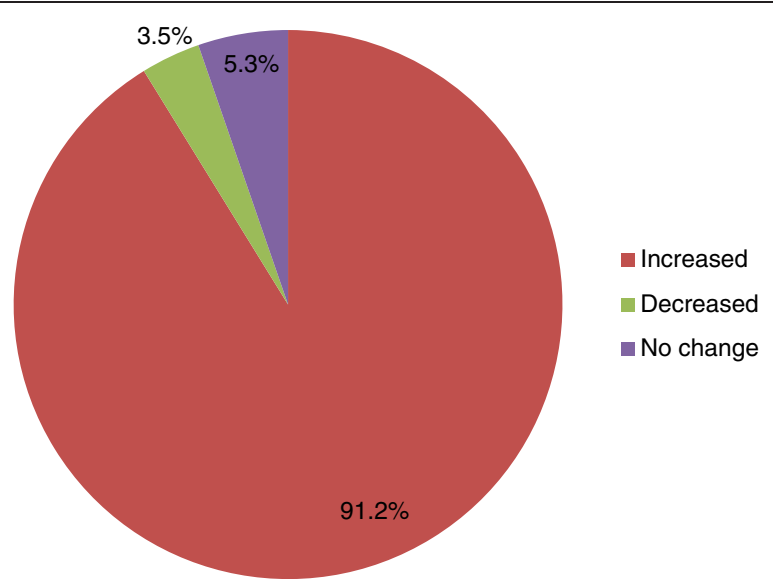

Figure 1 Farmers' perception of change in temperature due to climate change. The chart shows percent of respondents who perceived the different changes.

\section{Sources of information on the existence of climate change}

Farmers were explicitly asked how they first come to know about climate change (Figure 3). The majority of farmers (90 percent) perceived climate change through their life experience while 3.7 percent were informed by extension services. This result indicates that farmers are still heavily dependent on their gradual perception of climate change.

If Bayesian updating is assumed, this would mean that there is lack of information from extension services to update the perception of the farmers or the farmers attach less credibility (or probability of being true) to the information provided by extension staff.

\section{Types of adaptation strategies}

The majority of farmers (49.6 percent) adopted tree planting with at least one additional measure while 39.5 percent took tree planting as a sole response to climate change (Figure 4). A survey in the Nile Basin of Ethiopia (Deressa et al. 2011; Deressa et al. 2009) also found planting trees as the most common adaptation strategy. Planting trees has diverse ecological and economic benefits, which bring about adaptation to climate change. However, the responses of farmers to climate change can also be driven by their understanding of the causes of climate change. The majority (96 percent) of the households in this survey believe that the main cause for climate change is deforestation. Fosu-Mensah et al. (2010) also observed a similar understanding in Ghana. Therefore, planting trees may also be taken by the farmers partly as a mitigation strategy in addition to adaptation. Even though deforestation is one of the causes of climate change, it is known that carbon emission from industrialized countries is the main cause (IPCC 2007). Hence, the result shows the existing gap in the understanding of farmers on the main causes of climate change and a potential misconception on the performance of their major adaptation strategy- planting trees.

Although Figure 4 groups adaptation responses into three, there are actually 8 types of adaptation measures identified in the study area (Figure 5). The majority of farmers (89.1 percent) planted trees as an adaptation measure. Early planting, terracing, irrigation, and water harvesting follow tree planting as the next common adaptation strategies in the order they are listed. Praying was mentioned by 9.2 percent of the respondents as an adaptation strategy. Taking praying as a major adaptation measure may arise from associating 


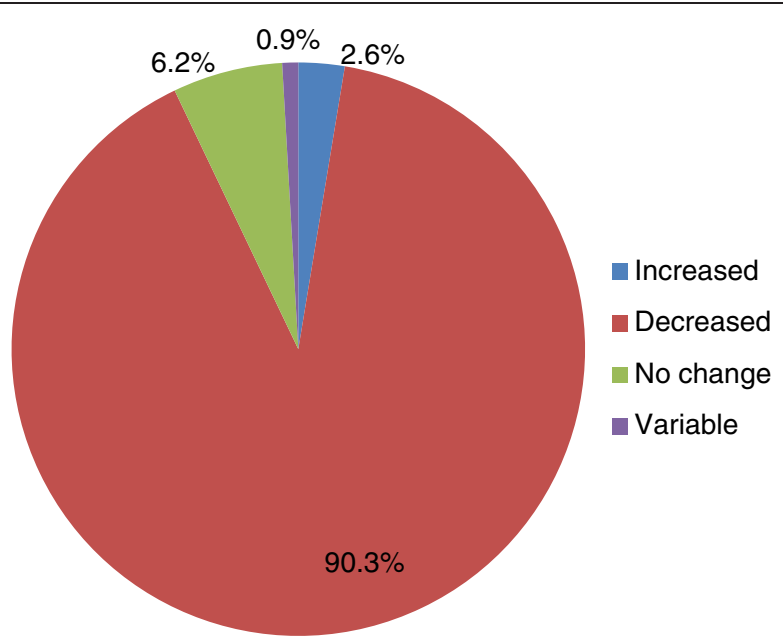

Figure 2 Farmers' perception of change in precipitation due to climate change. The chart shows percent of respondents who perceived the different changes.

climate issues to supernatural forces, which is usually the case in religious societies like Ethiopia (Nzeadibe et al. 2011). The use of early maturing plants and non-farm activity are rare responses to climate change in the study area. Generally, the adaptation measures taken by the farmers are similar to other findings in Ethiopia (Maddison 2007; Deressa et al. 2009; Deressa et al. 2011; Falco et al. 2011).

\section{Source of information on adaptation strategies}

Conley and Udry (2001) contend that farmers learn about new innovations from extension advice, from their own experimentation and from their neighbors' experimentation. In our survey, farmers were asked about their source of information on adaptation strategies. It was learned that extension advice took the lion's share (about $58.4 \%$ ) followed by own experimentation, which accounts $23.9 \%$ (Figure 6). Furthermore, $17 \%$ of the framers interviewed used neighbors' experimentation and advice as a source of information for adaptation. The results indicate the importance of extension services in influencing farmers' adaptation decisions. The dominance of tree planting as

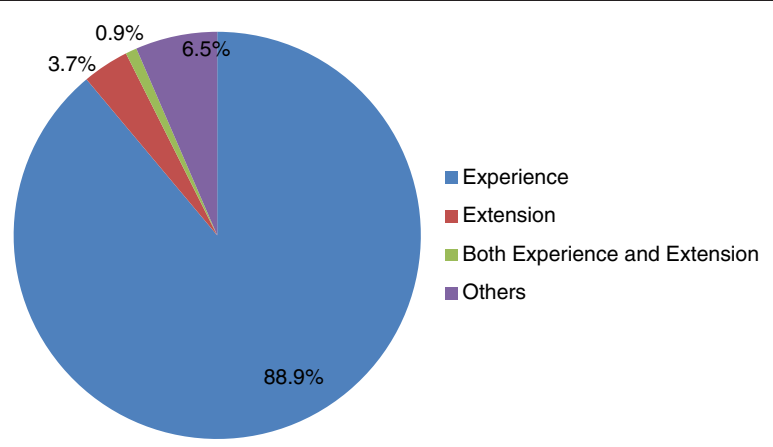

Figure 3 Source of information about climate change. The percent of respondents who mentioned the various sources of information is depicted in the figure. 


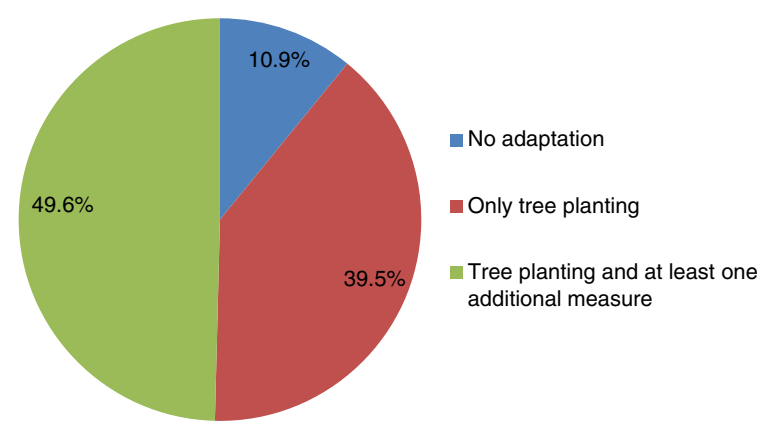

Figure 4 Adaptation strategies categorized into three. The chart shows the percent of respondents whose adaptation decisions fall in each of the three categories of adaptation.

an adaptation strategy may also be attributed to interventions by the public extension system, which is the main source of information on adaptation strategies.

\section{Determinants of adaptation}

The Multinomial Logit Model was run taking 'no adaptation' as the base category against which the remaining outcomes are compared with (Table 2). The model was checked for the endogeneity problem by fitting models with and without variables such as acess to extension services and acess to credit. Running Hausman specification tests showed that there is no significant systematic difference in coefficients as a result of exclusion of these variables.

An important assumption of the MNL is Independence of Irrelevant Alternatives (IIA) and the model was tested using the Hausman test to see if it fulfills the assumption. The Hausman test supported that IIA is not violated with $\chi^{2}$ ranging from 0 up to -35.53 with probabilities almost equal to 1.0. LR tests and Wald tests also verified the power of the explanatory variables included in the model. To make sure that the explanatory variables do not pose a multicollinearity problem, OLS was fitted and VIF was calculated. All the VIF values are less than $10(1.10-3.68)$ indicating that it is safe to assume the absence of multicollinearity.

For ease of interpretation, marginal effects were computed for each outcome in the dependent variable (see Table 3). The marginal effects show the change in probability of a particular choice of climate change adaptation for a unit change in the explanatory variables.

\section{Non-farm income}

Contrary to our hypothesis, non-farm income was showed to have a negative relationship with adaptation by employing tree planting with other measures. This could be explained by the enterprise diversification or risk reduction effect of non-farm income which may reduce the importance of urgent adaptation measures. In other words, the existence of nonfarm income serves as an adaptation measure by itself and may delay other responses.

\section{Farmer-to-farmer extension}

As was expected, farmer-to-farmer extension enhances adaptation to climate change, whether by only planting trees or by taking measures on top of tree planting. This result underscores the importance of social capital and informal extension services in adaptation to climate change. 


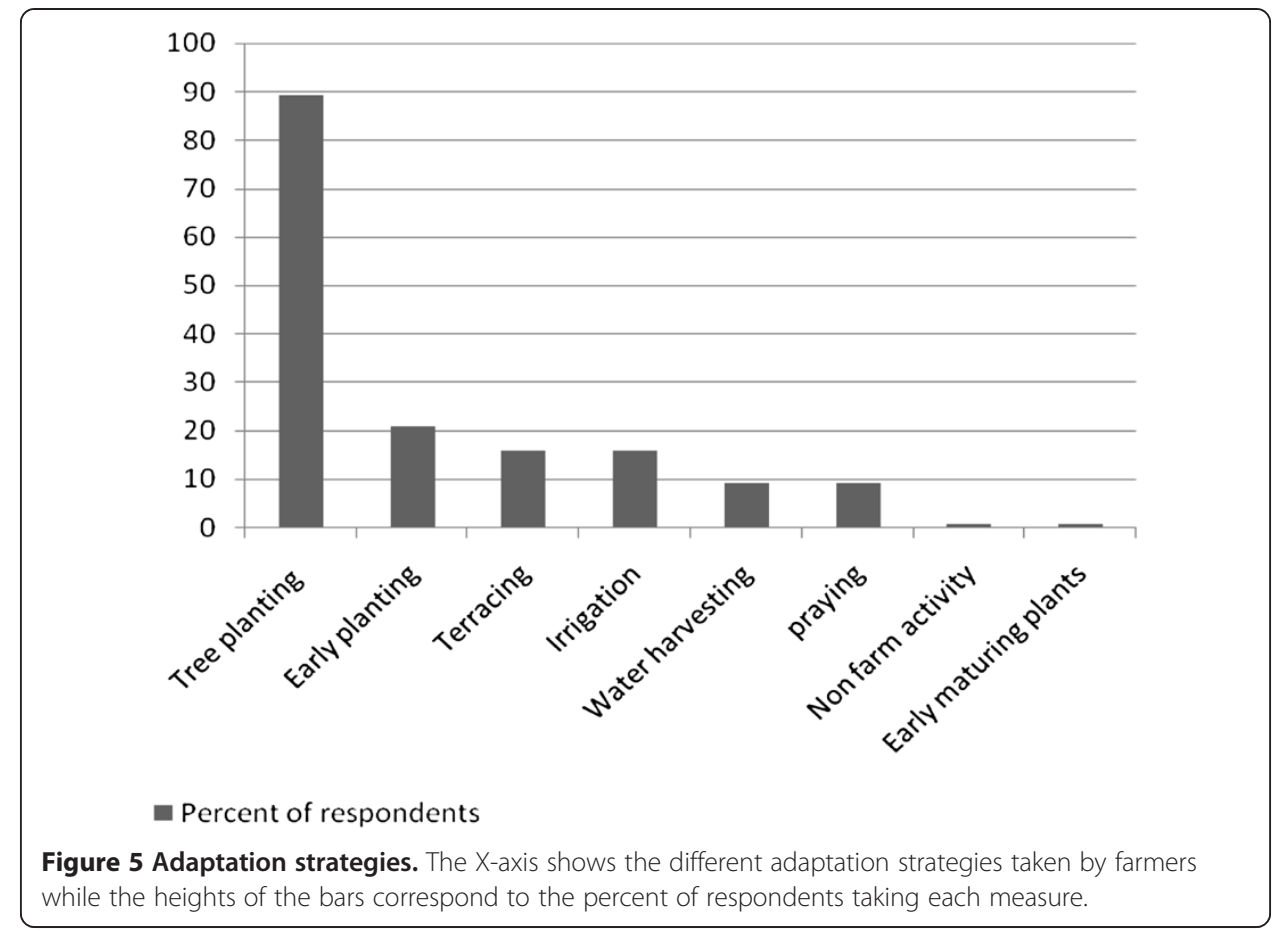

\section{Access to credit}

Regardless of the expectations, households with better access to credit were found to be less probable to adapt to climate change by tree planting as the only response for adaptation. Although not significant, the coefficient for adaptation by employing tree planting plus other measures is also negative. This could be explained by the fact that farmers accessing credit are likely to be already engaged in different farm investment activities which improves their adaptive capacity and thereby delaying adaptation measures.

\section{Distance to selling market}

As was hypothesized, as distance from selling market increases the likelihood of adaptation by tree planting trees and taking at least one additional measure decreases by 13.5 percent. Even though not statistically significant, it has the same negative relationship with adaptation by only tree planting.

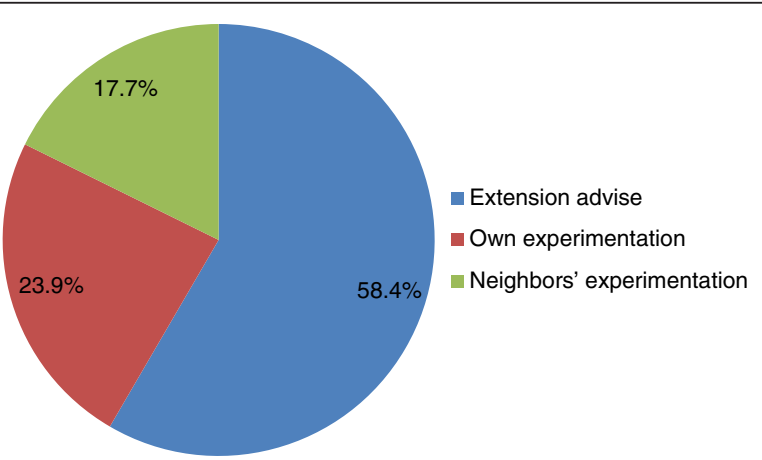

Figure 6 Source of information on adaptation strategy. The figure depicts the percent of respondents who use the different sources of information. 
Table 2 Parameter estimates of the multinomial logit model

\begin{tabular}{|c|c|c|c|c|}
\hline \multirow[t]{2}{*}{ Explanatory variables } & \multicolumn{2}{|c|}{ Only tree planting } & \multicolumn{2}{|c|}{$\begin{array}{l}\text { Tree planting and } \\
\text { other(s) }\end{array}$} \\
\hline & Coefficient & $P>|z|$ & Coefficient & $P>|z|$ \\
\hline Local agro-ecology (Mid-land) & -1.636667 & 0.281 & -.3587958 & .807 \\
\hline Non-farm income & -2.708249 & 0.145 & -3.288332 & $0.072^{*}$ \\
\hline Educational level of the household head-able to read and write & .0207302 & 0.989 & -.5278419 & 0.723 \\
\hline Education level of the household head-primary school or higher & 1.285579 & 0.479 & 1.445039 & 0.374 \\
\hline Gender of the household head & -1.903161 & 0.305 & -.2514557 & 0.884 \\
\hline Access to irrigation water & 2.221507 & 0.674 & 2.151656 & 0.683 \\
\hline Farming experience of the household head & -.0242545 & 0.539 & -.0402274 & 0.287 \\
\hline Farm size in hectares & .9027755 & 0.410 & .3203822 & 0.766 \\
\hline Access to food aid & 1.694316 & 0.289 & 1.665551 & 0.288 \\
\hline Land ownership & -1.185355 & 0.806 & -1.316571 & 0.783 \\
\hline Farmer to farmer extension & 4.930387 & $0.013^{* *}$ & 4.291278 & $0.027^{* *}$ \\
\hline Access to credit services & -3.473911 & $0.070^{*}$ & -2.471363 & 0.186 \\
\hline Access to extension services & .9831508 & 0.526 & -.9210263 & 0.498 \\
\hline Distance from selling market & -.375467 & 0.135 & -.9231534 & $0.003^{* * *}$ \\
\hline Distance from purchasing market & 2.185086 & $0.058^{*}$ & 3.196014 & $0.007^{* * *}$ \\
\hline Family size & -.1358245 & 0.587 & -.2319416 & 0.344 \\
\hline Annual income & .0002782 & $0.066^{*}$ & .0002397 & 0.109 \\
\hline Livestock ownership (TLU) & -.2087889 & 0.549 & -.2593202 & 0.444 \\
\hline constant & 1.568256 & 0.811 & 4.27316 & 0.508 \\
\hline \multicolumn{5}{|l|}{ Number of observations $=109$} \\
\hline \multicolumn{5}{|l|}{ LR chi2(36) = 79.39} \\
\hline \multicolumn{5}{|l|}{ Prob > chi $2=0.0000^{* * *}$} \\
\hline \multicolumn{5}{|l|}{ Log likelihood = -65.931038 } \\
\hline \multicolumn{5}{|l|}{ Pseudo R2 = 0.3758} \\
\hline No adaptation is the base outcome & & & & \\
\hline
\end{tabular}

$* * * * * *$ Significant at $1 \%, 5 \%$ and $10 \%$ significance level respectively.

\section{Distance to purchasing market}

Despite the expectations, the probability of higher level of adaptation increases with an increase in the distance of purchasing markets. With the increase in distance from purchasing markets, farmers are more probable (by 25.3 percent) to adapt by planting trees on top of at least one additional measure. It is also positively related with adaptation by only tree planting. The implication of this result is that farmers travelling further to purchasing markets may access larger markets where they are likely to be introduced with diverse inputs or technologies. The result further indicates that the markets from which distance is measured are not homogeneous, and underscores the need to verify the same while using the varibale as a measure for market access.

\section{Income}

In line with the hypothsis, income was found to be postively related with adaptation either by tree planting alone or by employing additional measures. Adaptation by tree planting plus at least one additional measure is, however, slightly insignificant $(\mathrm{p}=0.109)$. 
Table 3 Marginal effects from the multinomial logit model

\begin{tabular}{|c|c|c|c|c|c|c|}
\hline \multirow[t]{2}{*}{$\begin{array}{l}\text { Explanatory } \\
\text { variables }\end{array}$} & \multicolumn{2}{|c|}{$\begin{array}{l}\text { Only tree } \\
\text { planting }\end{array}$} & \multicolumn{2}{|c|}{$\begin{array}{l}\text { Tree planting and } \\
\text { other(s) }\end{array}$} & \multicolumn{2}{|c|}{ No adaptation } \\
\hline & Coefficient & $P>|z|$ & Coefficient & $P>|z|$ & Coefficient & $P>|z|$ \\
\hline Local agro-ecology (Mid-land) & -.3091525 & $0.053^{*}$ & .304948 & $0.055^{*}$ & .0042045 & 0.561 \\
\hline Non-farm income & .1317173 & 0.326 & -.1437625 & 0.285 & .0120452 & 0.455 \\
\hline $\begin{array}{l}\text { Educational level of the household head- } \\
\text { able to read and write }\end{array}$ & .1339774 & 0.454 & -.1355246 & 0.447 & .0015472 & 0.861 \\
\hline $\begin{array}{l}\text { Education level of the household head- } \\
\text { primary school or higher }\end{array}$ & -.0363438 & 0.870 & .0411828 & 0.852 & -.004839 & 0.505 \\
\hline Gender of the household head & -.3808178 & $0.041^{* *}$ & .3768494 & $0.042^{* *}$ & .0039684 & 0.532 \\
\hline Access to irrigation water & .0196342 & 0.941 & -.0135092 & 0.959 & -.006125 & 0.562 \\
\hline Farming experience of the household head & .0037983 & 0.398 & -.0039727 & 0.376 & .0001744 & 0.522 \\
\hline Farm size in hectares & .1424019 & $0.096^{*}$ & -.139461 & 0.104 & -.0029409 & 0.691 \\
\hline Access to food aid & .0104187 & 0.943 & -.0022303 & 0.988 & -.0081885 & 0.499 \\
\hline Land ownership & .0298371 & 0.899 & -.034039 & 0.884 & .0042019 & 0.711 \\
\hline Farmer to farmer extension & .1825314 & 0.228 & -.0853452 & 0.598 & -.0971861 & 0.354 \\
\hline Access to credit services & -.2390714 & 0.139 & 2052233 & 0.218 & .0338481 & 0.480 \\
\hline Access to extension services & .369668 & $0.005^{* * *}$ & -.3712651 & $0.005^{* * *}$ & .0015971 & 0.774 \\
\hline Distance from selling market & .1312373 & $0.013^{* *}$ & -.1348426 & $0.011^{* *}$ & .0036053 & 0.443 \\
\hline Distance from purchasing market & -.2389762 & $0.025^{* *}$ & .2533942 & $0.019^{* *}$ & -.014418 & 0.407 \\
\hline Family size & .0228787 & 0.354 & -.0238753 & 0.333 & .0009966 & 0.550 \\
\hline Annual income & $9.89 \mathrm{e}-06$ & 0.189 & $-8.56 \mathrm{e}-06$ & 0.256 & $-1.33 \mathrm{e}-06$ & 0.418 \\
\hline Livestock ownership (TLU) & .0117275 & 0.763 & -.0129662 & 0.739 & .0012387 & 0.536 \\
\hline
\end{tabular}

\section{Barriers to adaptation}

Adaptation to climate change has many stumbling blocks. During the survey, farmers mentioned a number of barriers to adaptation emanating from different social, economic and institutional situations (Figure 7). The most important factor mentioned as barrier to adaptation by the surveyed farmers is lack of information (which accounts $22.5 \%$ ) about climate change and adaptation strategies. This is attributed to various factors including lack of institutional support mechanisms and failure to mainstream the issue of climate change in the public extension system of the country. Lack of information was also identified as the main barrier to adaptation by a survey in the Nile Basin of Ethiopia (Deressa et al. 2009). Lack of farm inputs including seed (20.7 percent), chemical fertilizer (3.6 percent) and oxen (8.1\%) are mentioned by the respondents as the second most important impediments. Out of the three farm inputs mentioned by the framers, the problem emerging from lack of seed (20.7 percent) outweighs the other two while the problem from lack of drought oxen rests as the second most important barrier. According to 17.1 percent of the sampled respondents, shortage of land plays a key role in diminishing their potential to adapt to climate change. An independent sample t-test showed that these respondents have significantly $(\mathrm{p}<0.05)$ lower average land size compared to the rest of the respondents who did not mention shortage of land as a major barrier. The surveyed farmers also mentioned lack of money (14.4 percent) as another important climate change adaptation barrier. This result further 


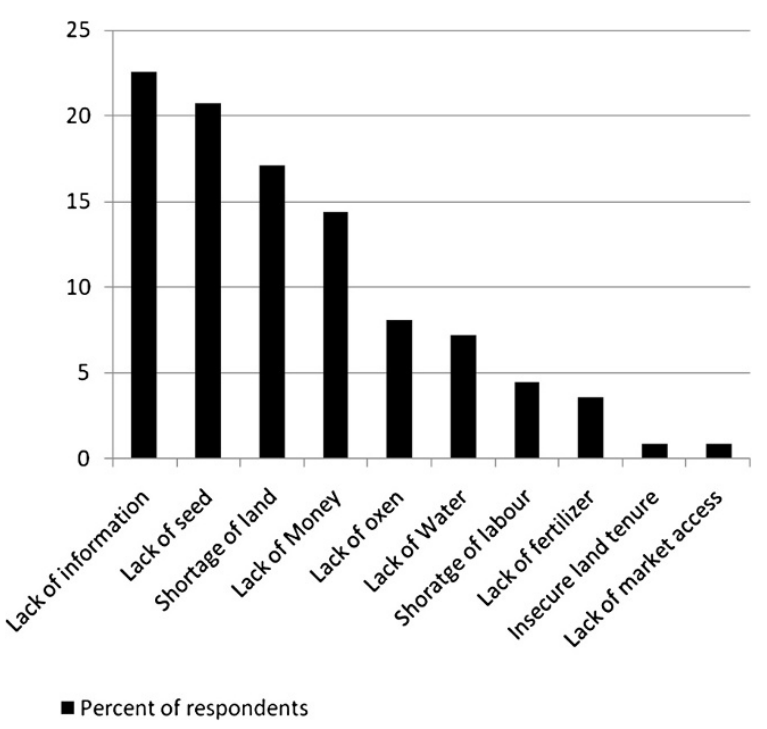

Figure 7 Barriers to adaptation. The $X$-axis shows the different barriers to adaptation faced by farmers while the heights of the bars correspond to the percent of respondents who mentioned each barrier.

signifies the importance of financial resources in adaptation to climate change. The other barriers mentioned by the farmers include: lack of water, lack of labor, insecure land tenure and lack of market access. In general, the findings are similar to other studies in the country (Deressa et al. 2009; Deressa et al. 2011; Bryan et al. 2009; Maddison 2007).

\section{Conclusions}

The research was carried out in three districts in East Hararghe Zone of Ethiopia where 110 farm households were randomly considered for the study. All of the surveyed farm households observed at least one type of climate change over the last 20 years primarily based on their life experience. Planting trees was found to be the single most common adaptation strategy in the study area. The majority of farmers (89.1 percent) adapted to climate change either by planting trees as a sole response or by taking at least one adaptation measure on top of it. Apart from tree planting, the main adaptation strategies taken by the households include: early planting, terracing, irrigation, water harvesting and praying. The majority of farmers learned about their adaptation strategies from extension services. Hence, the dominance of tree planting as an adaptation measure may be associated with the interventions of the extension system. Moreover, most farmers misconceived that the major cause of climate change is deforestation, which may indicate tree planting decisions could have been taken by the farmers partly as a mitigation strategy. There is a need to provide information to farmers and extension workers on the basics of climate change including its causes and what they should expect from tree planting as an adaptation strategy.

An MNL model was fitted on the data where the choices of adaptation to climate change make the dependent variable. Different socioeconomic, institutional and 
agro-ecological variables were hypothesized to influence adaptation decisions and were included in the model. Households with higher access to farmer-to-farmer extension, a proxy for social capital and access to informal extension services showed higher probability of taking adaptation responses. Farm households with higher income and better access to selling markets are more likely in taking adaptation measures. However, farmers tend to adapt more when they use purchasing markets located further. Farmers travelling to further input markets may be advantageous in being introduced with various technologies or inputs which increases their chance of adopting more adaptation strategies. This result also emphasizes the need to assess the homogeneity of markets before taking distance from markets as an indicator for market access.

With more non-farm income and credit, farmers will adapt less to climate change. Farmers with higher non-farm income may be slow in taking more adaptation measures as non-farm activities by themselves act as adaptation measures. Households who have access to credit may also be already engaged in different farm investments that improve their adaptive capacity to climate change, making less likely adaptive measures taken for climate change.

The surveyed farmers were asked about the most important barriers they face in adapting to climate change. The most frequently mentioned barrier is lack of information followed by lack of seed, shortage of land, lack of money, lack of oxen, lack of water, shortage of labor, lack of fertilizer, insecure land tenure and lack of market access, listed according to their importance. The result underscores the need for strengthening the extension system of the country in providing information on adaptation strategies and supplying agricultural inputs and particularly improved seeds. Enhancing the capacity of rural credit institutions is also an important element in supporting autonomous climate change adaptations at farm level.

In a nutshell, the study results indicate an information gap in the public extension system and among farmers about the causes of climate change, adaptation strategies and their performance. Planting trees as an adaptation measure should not be overemphasized and the extension system should introduce diverse adaptation options to climate change. Interventions that enhance income, access to finance, access to farm inputs, access to market and diversification of enterprises should be an integral part of climate change adaptation policies and strategies. It is also recommended that social capital should be utilized in national or regional interventions towards climate change adaptation of smallholder farmers.

Competing interests

The authors declare that they have no competing interests.

Authors' contribution

YAT came up with the initial idea for the research project and has been highly involved in data collection, analysis, interpretation and write up of the manuscript. CSA contributed ideas in the research proposal and has been also involved in data collection and write up of the manuscript. GSE contributed ideas in the research proposal and has been also involved in data collection and write up of the manuscript. All authors read and approved the final manuscript.

\section{Acknowledgement}

The authors are grateful for the valuable comments of three anonymous reviewers.

Author details

${ }^{1}$ School of Agricultural Economics and Agribusiness, Haramaya University, Dire Dawa, Ethiopia. ${ }^{2}$ Department of Rural Development and Agricultural Extension, Haramaya University, Dire Dawa, Ethiopia. 
Received: 11 December 2012 Accepted: 8 October 2013

Published: 21 Oct 2013

\section{References}

Abodi PN, et al. (2007) An Economic Assessment of Banana Genetic Improvement and Innovation in the Lake Victoria Region of Uganda and Tanzania. In: Smale M, Tushemereirwe WK (ed). International Food Policy Research Institute, Washington, D.C

ACCCA (2010) Farm - Level Climate change Perception and Adaptation in Drought Prone Areas of Tigray, Northern Ethiopia. Improving decision-making capacity of smallholder farmers in response to climate risk adaptation in three drought-prone districts of Tigray, northern Ethiopia Vol 3. Advancing capacity to Support Climate Change Adaptation (ACCCA), Mekelle

Adesina AA, Baidu-Forson J (1995) Farmers' perceptions and adoption of new agricultural technology: evidence from analysis in Burkina Faso and Guinea, West Africa. Agric Econ 13:1-9

Akponikpè PBI, Johnston P, Agbossou EK (2010) Farmers' perception of climate change and adaptation strategies in Sub-Saharan West-Africa. In: 2nd International Conference: Climate. Sustainability and Development in Semi-arid Regions, Fortaleza - Ceará, Brazil. ICID + 18

Allison P (2002) Sage Monograph on Missing Data, Sage paper \# 136. Sage, USA

Asfaw S, Shiferaw B, Simtowe F, Haile MG (2011) Agricultural technology adoption, seed access constraints and commercialization in Ethiopia. J Dev Agri Econ 3(9):436-447

Barrett CB (2006) Food Aid's Intended and Unintended Consequences. FAO, Rome

Bryan E, Deressa TT, Gbetibouo GA, Ringler C (2009) Adaptation to climate change in Ethiopia and South Africa: options and constraints. Environ Sci Policy 12:413-426

CIMMYT (1998) The Adoption of Agricultural Technology: A Guide for Survey Design. CIMMYT, Mexico, DF

Conley T, Udry C (2001) Social learning through networks: The adoption of new agricultural technologies in Ghana. Am J Agric Econ 83:668-673

Croppenstedt A, Demeke M, Meschi MM (2003) Technology adoption in the presence of constraints: the case of fertilizer demand in Ethiopia. Rev Dev Econ 7(1):58-70

CSA (2007) Statistical Tables for the 2007 Population and Housing Census of Ethiopia. Central Statistical Agency, Addis Ababa

CSA (Central Statistics Authority) (2004) The Federal Democratic Republic of Ethiopia Statistical abstract for 2003. CSA, Addis Ababa

Deressa TT, Hassan RM, Ringler C, Alemu T, d MY (2009) Determinants of farmers' choice of adaptation methods to climate change in the Nile Basin of Ethiopia. Global Environ Change 19:248-255

Deressa TT, Hassan RM, Ringler C (2011) Perception of an adaptation to climate change by farmers in the Nile basin of Ethiopia. J Agri Sci 149:23-31. 10.1017/S0021859610000687

Doss CR (2003) Understanding Farm-level Technology Adoption: Lessons Learned from CIMMYT's Micro Surveys in Eastern Africa. Economics Working Paper 03-07. CIMMYT, Mexico, DF

Falco SD, Yesuf M, Kohlin G (2011) What Adaptation to Climate Change? Evidence from the Nile Basin, Ethiopia. In: International Conference on Economics of Adaptation to Climate Change in Low-Income Countries. Ethiopian Development Research Institute and International Food Policy Research Institute, Washington, DC

Foster AD, Rosenzweig MR (2010) Microeconomics of Technology Adoption,Center Discussion Paper NO.984. Yale University, Newhaven, USA

Fosu-Mensah BY, et al. (2010) Farmers' Perception and Adaptation to Climate Change; A Case Study of Sekyedumase District in Ghana. World Food System - A Contribution from Europe, Zurich, Swizerland, Tropentag, International Research on Food Security, Natural Resource Management and Rural Development, Tropentag

Gbetibouo GA (2009) Understanding Farmers' Perceptions and Adaptations to Climate Change and Variability: The Case of the Limpopo Basin, South Africa (trans: Division EaPT). IFPRI-wide Discussion Paper. International Food Policy Research Institute, South Africa

Greene WH (2003) Econometric Analysis. Prentice-Hall, Upper Saddle RiverNJ

ILRI (2006) Mapping Climate Vulnerability and Poverty in Africa. International Livestock Research Institute, Nairobi, Kenya

IPCC (2001) Climate Change 2001: Synthesis Report. A Contribution of Working Groups I, II, III to the Third Assessment Report of the Intergovernmental Panel on Climate Change. R. T. Watson and the Core Team, Cambridge and New York, p 398

IPCC (2007) Climate Change 2007: The Physical Science Basis. Contribution of Working Group I to the Fourth Assessment Report of the Intergovernmental Panel on Climate Change, Cambridge, United Kingdom and New York, NY, USA

Isham J (2000) The Effect of Social Capital on Technology Adoption: Evidence from Rural Tanzania. Opportunities in Africa: Micro-evidence on Firms and Households. The Centre for the Study of African Economies, University of Oxford, Oxford

Jack (2011) Constraints on the adoption of agricultural technologies in developing countries. White paper, Agricultural Technology Adoption Initiative. J-PAL (MIT) and CEGA, UC Berkeley

Jariko GA, Junejo MA, Rahpoto MS, Shah MZ (2011) Socioeconomic factors affecting adoption of sunflower varieties in Sindh. Pak J Commer Soc Sci 5(1):192-201

Katungi EM (2007) Social Capital and Technology Adoption on Small Farms: The Case of Banana Production Technology in Uganda. PhD Dessertation. Department of Agricultural Econmics, Extension and Rural Development, University of Pretoria, Pretoria

Lautze S, Aklilu Y, Raven-Roberts A, Young H, Kebede G, Leaning J (2003) Risk and Vulnerability in Ethiopia: Learning from the Past, Responding to the Present. Preparing for the Future, Addis Ababa

Long JS, Freese J (2001) Regression Models for Categorical Dependent Variables Using Stata. A Stata Press Publication, STATA Corporation, College Station, Texas

Madalla G (1983) Limited Dependent and Qualitative Variables in Econometrics. Cambridge University Press, Cambridge 
Maddison D (2007) The Perception of an Adaptation to Climate Change in Africa. Policy Research Working Paper. The World Bank, Development Research Group, Sustainable Rural and Urban Development Team, Pretoria, South Africa

Maharjan SK, Sigdel ER, Sthapit BR, Regmi4 BR (2011) Tharu community's perception on climate changes and their adaptive initiations to withstand its impacts in Western Terai of Nepal. Int NGO J 6(2):35-42

McSweeney C, Lizcano G, New M, Lu X (2010) The UNDP Climate Change Country Profiles. Available via http://journals. ametsoc.org/doi/abs/10.1175/2009BAMS2826.1. Accessed 26 Nov 2012)

Nhemachena C, Hassan RM (2007) Micro-Level Analysis of Farmers' Adaptation to Climate Change in Southern Africa. IFPRI Discussion Paper No. 714, vol 15-7. International Food Policy Research Institute, Washington, DC

Niemistö N (2011) The resilience of rural Ethiopian livelihoods, a case study from Hararghe zone. University of Jyväskylä, Eastern Ethiopia

Nzeadibe TC, Egbule CL, Chukwuone NA, Agu VC (2011) Climate Change Awareness and Adaptation in the Niger Delta Region of Nigeria. African Technology Policy Studies Network, Nairobi

ONRSPO (n.d) Socio-economic Profile of East Hararghe. Oromia National Reginal State President Office. Available via http://www.oromiyaa.com/index.php?option = com_content\&view $=$ category\&layout $=$ blog\&id $=114 \&$ ltemid $=788$. Accessed 10 Dec 2012

Paudel K, Pandit M, Mishra A, Segarra E (2011) Why Don't Farmers Adopt Precision Farming Technologies in Cotton Production? In: Agricultural \& Applied Economics Association's 2011 AAEA \& NAREA Joint Annual Meeting. Agricultural and Applied Economics Association, Pittsburgh, Pennsylvania

Smit B, Pilifosova O (2001) Adaptation to Climate Change in the Context of Sustainable Development and Equity. Contribution of the Working Group to the Third Assessment Report of the Intergovernmental Panel on Climate Change. Cambridge University Press, Cambridge, UK, pp 879-912

Sofoluwe NA, Tijani AA, Baruwa OI (2011) Farmers' perception and adaptation to climate change in Osun State, Nigeria. Afr J Agri Res 6(20):4789-4794

Stige LC, Stave J, Chan K, Ciannelli L, Pattorelli N, Glantz M, Herren H, Stenseth N (2006) The effect of climate variation on agro-pastoral production in Africa. PNAS 103:3049-3053

Strzepek K, Mccluskey A (2006) District Level Hydro-climatic Time Series and Scenario Analysis to Assess the Impacts of Climate Change on Regional Water Resources and Agriculture in Africa. CEEPA Discussion Paper No. 13, Pretoria, South Africa

Tadege A (2007) Climate Change National Adaptation Program of Action (NAPA) of Ethiopia. NMS (National Meteorological Agency), Federal Democratic Republic of Ethiopia Addis Ababa

Uaiene RN, CA, Masters WA (2009) Determinants of Agricultural Technology Adoption in Mozambique. Ministry of Planning and Development, Republic of Mozambique

Vedwan N, Rhoades RE (2001) Climate change in the Western Himalayas of India: a study of local perception and response. Climate Res 19:109-117

Wilson K, Getnet M (2011) Investigating how development interventions increase community-level adaptive capacity in Ethiopia. In the New Voices, Different Perspectives: Proceedings of the AfricaAdapt Climate Change Symposium 2011. Addis Ababa, Ethiopia

Yirga CT (2007) The dynamics of soil degradation and incentives for optimal management in Central Highlands of Ethiopia. University of Pretoria, Pretoria, South Africa

10.1186/2193-7532-1-13

Cite this article as: Tessema et al:: Understanding the process of adaptation to climate change by small-holder farmers: the case of east Hararghe Zone, Ethiopia. Agricultural and Food Economics 2013, 1:13

\section{Submit your manuscript to a SpringerOpen ${ }^{\circ}$ journal and benefit from:}

- Convenient online submission

- Rigorous peer review

- Immediate publication on acceptance

- Open access: articles freely available online

- High visibility within the field

- Retaining the copyright to your article

Submit your next manuscript at $>$ springeropen.com 